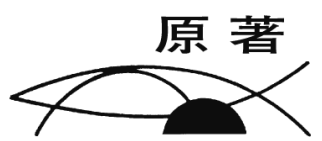

\title{
人工鼻フィルター $(\mathrm{HMEF})$ が加湿不足あるいは 加湿過剩をきたす換気条件に関する定量的研究
}

\author{
秋元郁美 ${ }^{*}$, 中野順子 ${ }^{* 1}$, 鴨志田麻実子 ${ }^{* 1}$, \\ Study of the Performance of a Heat and Moisture Exchanger Filters in Extreme Conditions. \\ Ikumi Akimoto* $^{*}$ Junko Nakano*1, Mamiko Kamoshida ${ }^{* 1}$
}

Abstract

Heat and moisture exchanger filters (HMEFs) are commonly used in mechanical ventilation practices. We described the performances of HMEF in extreme conditions which may decrease expected moisture returns from HMEF. The experiments with dry gases were performed on the model lung-ventilator system. The test lung with soaked cotton inside was placed in the incubator where temperature was maintained at $37^{\circ} \mathrm{C}$.

Relative (RH) and absolute humidity and temperature of the circuit was measured electronically (Maphy+, S.K.I. Net, Inc.).

The results showed, firstly, RH went down below $90 \%$ when minute volume exceeded $12 \mathrm{~L} / \mathrm{min}$. Secondary, air leak of $20 \%$ of the inspiration volume decreased RH below $90 \%$ when inspired minute volume exceeded $8 \mathrm{~L} / \mathrm{min}$. Thirdly, addition of unheated cascade humidifier kept $\mathrm{RH}$ of the circuit at $100 \%$ in both of the above conditions throughout the minute volume of up to $20 \mathrm{~L} / \mathrm{min}$ by providing additional humidity of between 6 and $12 \mathrm{mg} / \mathrm{L}$. We also reported additional effects of the atmospheric humidity as turbine ventilator inspired room air instead of dry gasses. Water content of HMEF increased approximately 8 grams in seasons of high humidity whereas, that with dry gases was constantly $1.5 \pm 0.3$ grams $(n=39)$. HMEF with water content of 8grams increased the inspiratory airway resistance by $33 \%$.

\section{1. 目的}

気管チューブや気管切開チューブなど人工 気道を用いて人工呼吸を継続する場合, 加温と 加湿は必須であり，この目的で人工鼻フィルタ 一 (HMEF) が広く用いられている1). しかし, 臨 床上, HMEF で加湿不足となったり, 加湿過

* 平成会病院 看護部

*1 平成会病院リハビリテーション科 （原稿受付：2013 年 12 月 10 日）
剩となる場合のあることが報告されている ${ }^{2)}$. そこで本研究では, 通常の場合と異なって加湿 不足あるいは加湿過剩となる以下の 4 点の場合 を想定して定量的に研究した.

1 ）分時換気量が大きく，10L/分を超えるよ うな場合 (加湿不足).

2) 気管切開チューブのカフ周囲からのエアリ ークが続く場合あるいは, 気胸から胸腔ド レーンを介してリークが続く場合（加湿不 足).

3) 加湿補助法としてカスケード型の加温加湿 
（34）医機学 Vol.84, No. 3 (2014)

器のチャンバを非加熱で併用した場合の 効果 (加湿補助).

4) タービン型人工呼吸器では, ドライガスで はなく大気を吸入させる。 そこで大気湿度 の变化が HMEF の気道抵抗特性に与える 影響 (加湿過剩), などについて検討した.

\section{2. 方 法}

ドライガスを用いた実験装置の概要を図 1 に示した．テスト肺（MAQUET190）に化繊 綿を詰めて $20 \mathrm{ml}$ の蒸留水を注入した。 これを 恒温槽 (KINGSURO20, Rcom) 内で, $37^{\circ} \mathrm{C} に$ 保った。恒温槽内の温度は, サーミス夕 (CT280WR，カスタム）で連続的に測定した。テス ト肺にカテーテルマウント, HMEF, 呼吸器 回路を接続した。 人工呼吸器 Servo-S（フクダ 電子）の換気モードは従量式として一回換気量 を 500ml, PEEP =0, I : E = 1：2 に固定 した.

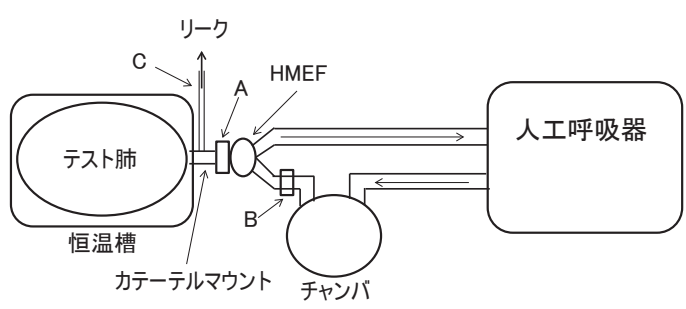

実験装置の概要。テスト肺は, 恒温槽内で $37^{\circ} \mathrm{C} に$ 保った。 $\mathrm{A}$, $\mathrm{B}$ ：温室度・圧力モニターMUPHY+の設置位置を示す。C： リーク量の調節回路. リークの量は, クレンメで調節した.

図 1

換気回数を $8 \sim 40$ 回で変化させ, 分時換気 量 4，8，12，16，20L /分において測定した. 回路の温度と湿度は, 温・湿度・圧力モニター $\mathrm{MAPHY}+$ (スカイネット) で測定して 1 サ イクルの呼吸の最大值を求めた。 そして, 連続 する 5 サイクルの平均を求めた.

今回作成した実験装置は, 分時換気量 $8 \mathrm{~L} /$ 分の条件下で 3 時間以上に渡ってカテーテルマ ウント部位（図 $1 \mathrm{~A}$ ）の相対湿度 $100 \%$, 絶対 湿度 $26.5 \pm 0.5 \mathrm{mg} / \mathrm{L}$, 温度 $27.2 \pm 0.4^{\circ} \mathrm{C}$ を保っ た. 従って, ヒト肺の in vitro 実験モデルとし て適当であると考えた。

回路のリーク量を調節するために, テスト肺
とカテーテルマウントの間にルアーロック側孔 付きのアダプターを設置して輸液回路を接続し た(図 1 C).リーク量は, クレンメで調節した.

HMEFによる加湿不足に対する加湿補助 法として, 必要に応じて吸気回路の途中に注 水したカスケード型の加温加湿器のチャンバ (MR290F\&P 社) を非加熱で併用した. この場 合の測定点は, チャンバの吐出口と HMEF の 間とした（図 $1 \mathrm{~B})$.

HMEF による加湿過剩を想定したタービン 型人工呼吸器の場合は室内空気を患者に供給 する，従ってドライガスとは異なり，人工呼 吸器の回路内湿度は大気湿度の影響を受ける. そこで, 1 年を通じて HMEF 重量を電子天 秤（CS-320D, Yuyama）を用いて測定し, 室 内湿度と対応させた. HMEF 重量の増加は, HMEF 内の水分増加量に一致すると考えた. 対象は, タービン型人工呼吸器（クリンエア VS ULTRA，フクダライフテック）装着患者 で分時換気量が 4 7 L/分とし, 年齢, 性別, 疾患は問わなかった，対象患者の人工呼吸器回 路に新たな $\mathrm{HMEF}$ を装着し, 24 時間後に電子 天秤を用いて HMEF 重量を計測した. HMEF に明らかに喀痰が付着した場合は, 測定対象か ら除外した。室内温度, 湿度, 大気圧はデー タロガー TR-73U（T\&D 社）を用いて 24 時間 の平均值を求めた. $\mathrm{HMEF}$ 重量（水分量）の 増加に対応する気道抵抗は, 圧縮空気型人工呼 吸器サーボー i (フクダ電子) を用い, 従量 式, 換気量 $500 \mathrm{ml}$, 呼吸数 12 回, PEEP 0 , I : E 比 $1 ： 2$, 休止時間 $15 \%$, 立ち上がり $0 \%$ ，圧トリガー -20 に設定した。 テスト肺 (MAQUET -190) を接続し，5吸気目の吸気 抵抗を測定した. HMEFの加湿には, 蒸留水 を接続したインスピロンアクサーム III ネブライ ザーヒーター（インターメドジャパン）を用い た. HMEF を加湿して重量増加(水分量の増加) が $4 \mathrm{~g} \sim 12 \mathrm{~g}$ の間で吸気抵抗を測定した.

全ての実験は，暖房と冷房でコントロールさ れた室内温度 $25 \pm 0.5^{\circ} \mathrm{C}$ でおこない, HMEF は, インターサーム 1341000S（インターサージカ ル）を用いた. In vitroの実験の場合は，5個 の計測值の平均值と標準偏差を求めた. 統計学 
的有意差検定には, studentの $\mathrm{t}$ 一テストを用 い, $\mathrm{p}<0.05$ を有意差ありとした。患者を被 験者とする場合は, 実験が患者の不利益となら ないことを確認し, 当院倫理委員会で承認を得 た. 人工呼吸の分野では, 回路の目視のために 相対湿度が重視されているので, 結果の表記は 絶対湿度と相対湿度を併記した。

\section{3. 結 果}

\section{1 ) 加湿不足となる換気条件}

分時吸気量を $4 \sim 20 \mathrm{~L} /$ 分の間で変化さ せた場合, 吸気量 $12 \mathrm{~L} /$ 分以下では全ての HMEF で相対湿度は $100 \%$, 絶対湿度は約 30mg / L だった（図 2)。しかし，吸気量が $16 \mathrm{~L} /$ 分を超えると, いくつかの HMEF では 相対湿度が $100 \%$ 以下となり, 吸気量 $20 \mathrm{~L} /$ 分では HMEF の一つは相対湿度が $88 \%$ となっ た。

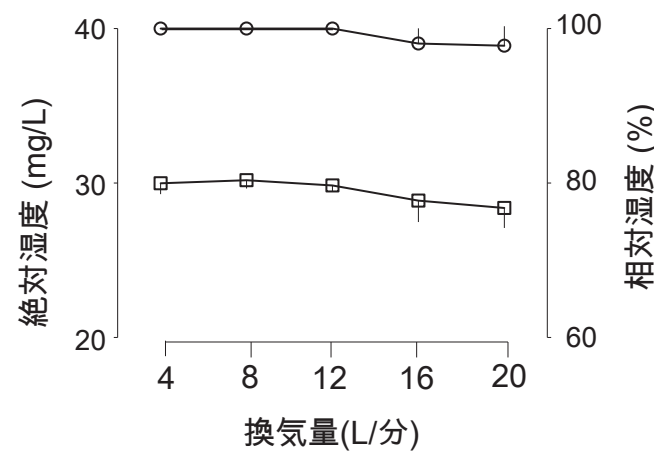

分時換気量を変化させた場合の絶対湿度 $(\square)$ と相対湿度 (○）の変化. 温室度 ・ 圧力モニターMUPHY+の設置位置 は図 $1 \mathrm{~A}$.

図2

\section{2）リークによる加湿不足と加湿補助の効果} 吸気量に対して $20 \%$ のリークを回路に作成 した場合, 分時吸気量が $12 \mathrm{~L} /$ 分（分時呼気 量 $9.6 \mathrm{~L}$ ／分）を超えると, カテーテルマウン ト内の相対湿度は $100 \%$ 以下となった（図 3 ).

これら加湿不足の場合に, 加湿補助として 非加熱チャンバを吸気側にカスケード接続する と, 全ての場合でカテーテルマウント内に露滴 を認め, 相対湿度が $100 \%$ となった。

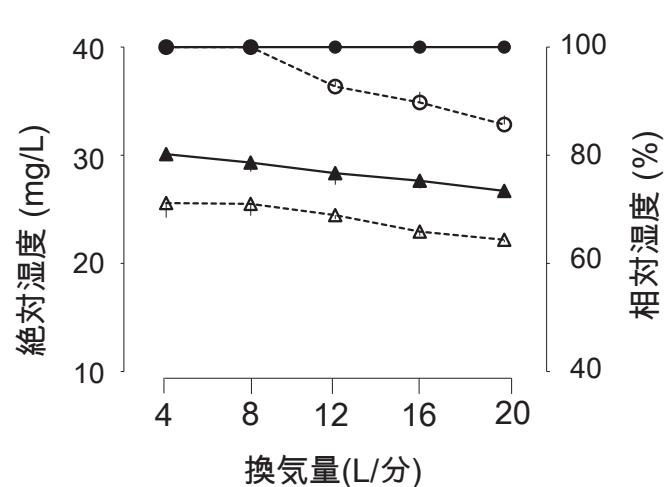

回路に20\%のリークを設けた場合（破線）と, 非加熱チャン バを追加した場合 (実線) の絶対湿度 $(\triangle)$ と相対湿度 $(\bigcirc)$.

図3

\section{3）非加熱カスケード型の加温加湿器のチ ヤンバの加湿効果}

ドライガスが非加熱のチャンバを通過する ことによって, どの程度加湿されるか(温·湿度· 圧力モニターMAPHY + を図 1 B の位置に設 置)について，換気量 4 から $20 \mathrm{~L} /$ 分の間で 測定した.この間, $6 \sim 12 \mathrm{mg} / \mathrm{L}$ 程度, 加湿 された（図 4).

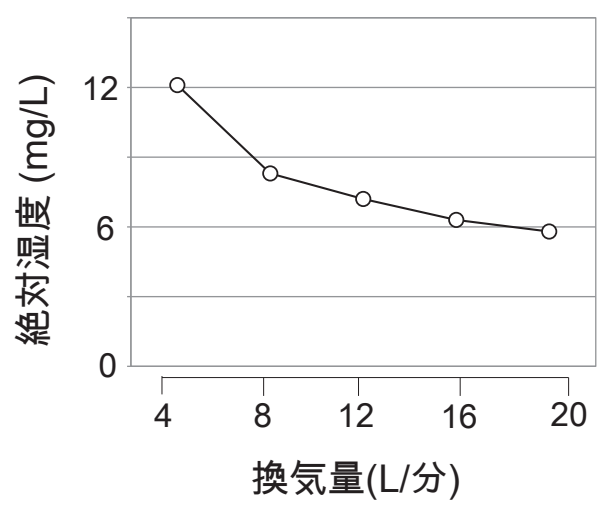

非加熱チャンバの加湿補助効果. 温室度 ·圧力モニター MUPHY+の設置位置は図1B.

図4

\section{4) タービン型人工呼吸器による HMEF の 加湿過剰 \\ タービン型人工呼吸器に接続した HMEF の} 重量増加と室内湿度との関係を図 5 に示した. HMEF の重量は, 室内の絶対湿度に相関して $1 \sim 8 \mathrm{~g}$ 程度増加した $(\mathrm{y}=0.42 \mathrm{x}+0.14, \quad \mathrm{r}$ $=0.76)$. 比較のために, 圧縮空気型人工呼吸 


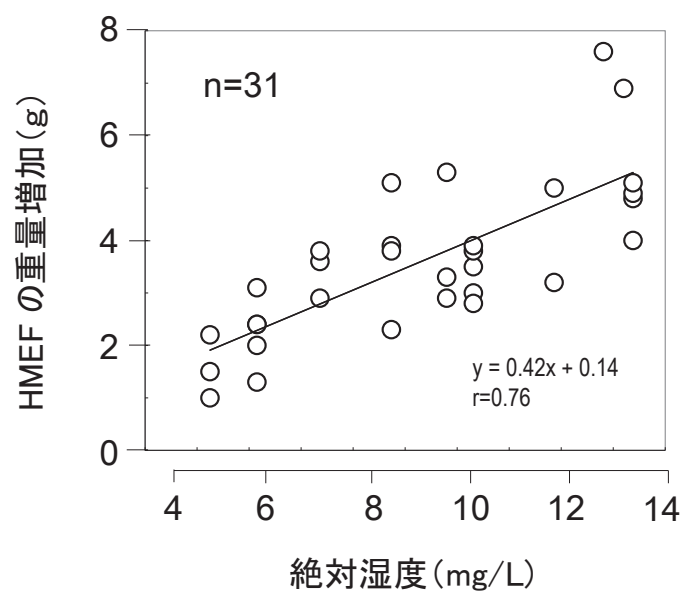

タービン型人工呼吸器におけるHMEFの重量増加（水分増 加）量と室内湿度（絶対湿度）との関係. 両者の相関は, $\mathrm{y}=0.42 \mathrm{x}+0.14, \quad \mathrm{r}=0.76$

図5

器に接続した HMEF の重量を同様の方法で測 定した所, 重量の増加は年間を通じてほぼ一定 で, $1.5 \pm 0.3 \mathrm{~g}(\mathrm{n}=39)$ であった.

次に, HMEFの重量増と気道抵抗の変化 について図 6 に示した. HMEF を接続せず, テスト肺のみを装着した時の吸気抵抗は 12 $\mathrm{cmH}_{2} \mathrm{O} / \mathrm{L} /$ 秒であった。 無加湿の $\mathrm{HMEF}$ を 接続した場合の吸気抵抗は $15 \mathrm{cmH}_{2} \mathrm{O} / \mathrm{L} /$ 秒 であった. HMEF の重量増加（水分量の増加） が $4 \sim 12 \mathrm{~g}$ の範囲で, 吸気抵抗は $15 \sim 20$ $\mathrm{cmH}_{2} \mathrm{O} / \mathrm{L} /$ 秒であった. この変化について,

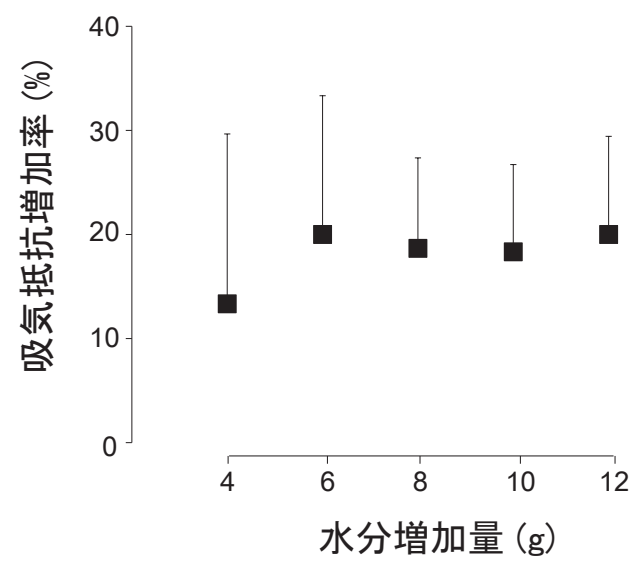

HMEFの水分重量増と吸気気道抵抗の関係. 吸気気道抵抗 は増加する傾向を認めたが, いずれの場合も有意差を認めな かった $(\mathrm{p}<0.05)$.

図6
無加湿の HMEF を接続した場合の吸気抵抗 $15 \mathrm{cmH}_{2} \mathrm{O} / \mathrm{L} /$ 秒に対する増加率として求め ると，増加率は $0 \sim 33 \%$ の範囲にあった。し かし, 異なる水分増加量に打ける吸気抵抗の増 加率の間にはいずれも有意差を認めなかった.

\section{4. 考察}

加湿不足と非加熱チャンバの加湿補助効果 市販されている HMEF の大部分は, $30 \mathrm{mg} /$ L 強の加湿能力がある ${ }^{3)}$. 未梢気道は，1日に 約 $300 \mathrm{ml}$ の不感蒸泄によって体温 $37^{\circ} \mathrm{C}$ の時, 相対湿度 $100 \%$ （絶対湿度 $44 \mathrm{mg} / \mathrm{L}$ ， 飽和水 蒸気圧 $63 \mathrm{hPa}$ ）に保たれる ${ }^{4)}$. しかし人工気道 部分では粘膜からの不感蒸泄は失われる。この ため, カテーテルマウント内の相対湿度が 100 $\%$ 未満になると，人工気道内の相対湿度は 100 \%以下となり, 人工気道内及び周辺の喀痰から 水分が蒸発して固くなり，カテーテル内部を閉 塞させる場合もあると思われる ${ }^{5,6)}$.

一般に, HMEF と加温加湿器を併用するこ とは加湿過剩によって HMEF が閉塞する危険 があるので禁忌とされる ${ }^{7}$. 一方, Suzukawa らは, 室温で非加熱の加温加湿器のチャンバを 吸気回路に追加した場合の回路内の湿度につい て詳細に研究し, 室温で非加熱のチャンバを通 過後, ドライガスは $13 \mathrm{mg} / \mathrm{L}$ 程度加湿される ことを報告した ${ }^{8)}$ 。この值は，本研究の成績と ほぼ一致する．本研究の成績は, HMEF で加 湿不足となる換気条件下であっても，室温で非 加熱の加温加湿器のチャンバを吸気回路に追加 することによって，カテーテルマウント内の相 対湿度を $100 \%$, 絶対湿度 $28 \mathrm{mg} / \mathrm{L}$ 以上に保 つことができることを示した。臨床の現場にお いて, 加温加湿器チャンバを非加熱で使用する 方法は気道の乾燥を防ぐ方法として安全且つ簡 便有用であると思われる.

HMEF をタービン型人工呼吸器に使用する と, HMEF 内の水分量が大きく変動すること を認めた。この理由は, タービン型人工呼吸器 はドライガスを吸入させる圧縮空気型人工呼吸 器とは異なり，室内空気を直接患者に供給する ことに起因すると思われた，HMEF の水分増 加量を比較すると, 圧縮空気型においては, 室 
内湿度の変化に関わらず僅か $2 \mathrm{~g}$ 未満と一定で あった. 他方, タービン型では冷暖房で年間を 通じてほぼ一定の室温に調節された環境下にお いても約 $8 \mathrm{~g}$ に達する場合があった. 高湿度が 持続する環境下では, HMEF の水分量が増加 して気道抵抗を上昇させる可能性があると思わ れる ${ }^{9)}$. 本研究では, HMEF の水分増加が吸 気抵抗を増加させる傾向を認め, 中には $30 \%$ 以上吸気抵抗が増加する HMEF があった。し かし今回, 両者の間に統計学的に有意差のある 関連性は認めなかった。 室内湿度が上昇すると H M E F が加湿過剩となって, 患者の吸気努力 の上昇, 吸気トリガー感知あるいは気道内圧の 上昇など，呼吸状態に影響を与える可能性があ る ${ }^{10)}$. 患者の観察とともに, HMEF とカテー テルマウントの湿潤状態の観察と, 療養環境の 空調管理の重要性が示唆された。

\section{5. 結 論}

1 ）分時換気量が 10 Lを超えると HMEF のみ では加湿不足となる。

2 ）気管切開チューブのカフ周囲からのエアリ ークが続く場合あるいは, 気胸から胸腔ド レーンを介してリークが続く場合は加湿 不足となり易い.

3 ) HMEF のみで加湿不足となる場合, カス ケード型の加温加湿器のチャンバを非加 熱で併用すると安全且つ簡便な加湿補助 法となる.

4) タービン型人工呼吸器では, ドライガスで はなく大気を吸入させるので, 室内湿度の 変化が HMEF 内の水分量を変化させて加 湿過剩となる場合がある。

\section{文献}

1 ) 山村剛康, 福田正人, 平清水智実: 長期人工 呼吸症例の加温. 加湿. 呼吸器ヶア. 7 月号 : p.48-51. 2009.

2 ) 田中京子, 井上裕美子, 福田正人：気道の加 湿が有効であった気管拡張による持続的カフ 漏れの 1 例. 人工呼吸. 30 巻 1 号: p.53-57. 2013.

3 ) ISO document 9360-1. Anesthetic and respiratory equipment-Heat and moisture exchangers (HMEs) for humidifying respired gasses in humans. ISO 9360-1 : 2000 (E) . 2000.

4) 真島英信 : 不感蒸泄. 生理学 (改訂 18 版). 文光堂 : p.491-502. 1990.

5 ) 磨田裕: 加温加湿と気道管理. 人工気道での 加温加湿をめぐる諸問題. 人工呼吸. 27 巻 : p.57-63. 2010.

6 ）並木昭義, 氏家良人. 気道の生理的機能. よ くわかる人工呼吸管理テキスト (改訂第 4 版). 南江堂 : p.99-111. 2007.

7 ) 厚生労働省 : 人工呼吸器回路における人工鼻 と加温加湿器の併用に係る添付文書の自主点 検等について. 薬食審査発第 0911003 号, 薬 食安発第 0911001 号. 2008.

8) Masayuki Suzukawa, Yutaka Usuda, Katsuo Numata: The Effects on Sputum Characteristics of Combining an Unheated Humidifier with a Heat-Moisture Exchanging Filter.Respir Care. 34 : p.976-984. 1989.

9 ）木村政義：人工鼻フィルターの流量抵抗に ついての検討. 人工呼吸. 2003 年 10 月号： p159. 2003.

10）田中淳, 市山智義, 他: 人工鼻フィルターが 呼吸トリガーに及ぼす影響. 医器学.76 (10): p589-590. 2006. 